Journal of EST, Volume 1, Nomor 2,. September 2015 hal 8 - 19

ISSN: $2460-1497$

\title{
PENGARUH KERJA TIM TERHADAP KINERJA GURU SMP
}

\author{
Muhammad Basir \\ Ahli Ilmu Pendidikan \\ STKIP Puangrimaggalatung Sengkang \\ Email : Basir.muhammad57@gmail.com
}

\begin{abstract}
ABSTRAK
The research aims to The Influence of team work to teacher's performance at Public Yonior High Scool of state in Wajo. The research used quantitative of causal. The population of this study are all Junior High School the number in 52 School and 744 teachers had status of civil servant. The sample of this study consisted of 294 respondents of teacher are established in Cluster Random Sampling. The data were collected by using questionnaire for examining the pattern of relationship established and by using path analysis. The result of the research indicates that team work have positive and significant impact indirectly on teacher achievement. Conclusion of the research are all variable had positive and significant effect on teacher achievement at Junior High School in Wajo. Its means that all variable in this research had important role for the quality improvement on the teacher achievement.
\end{abstract}

Keywork : team work, teacher's performance

\begin{abstract}
ABSTRAK
Penelitian ini bertujuan untuk mengetahui hubungan antara kerja tim terhadap kinerja guru pada SMP negeri Kabupaten Wajo, Pendekatan yang digunakan dalam penelitian ini adalah pendekatan kuantitatif yang bersifat kausal. Populasi penelitian adalah Sekolah Menengah Pertama yang berjumlah 52 Sekolah, dan 744 guru yang telah berstatus Pegawai Negeri Sipil. Sampel untuk responden penelitian ini 294 guru yang ditentukan secara Claster Random Sampling, pengumpulan data dilakukan dengan menggunakan kuesioner, untuk menguji pola hubungan model yang dibentuk, digunakan analisis jalur ( Path Analysis). Hasil penelitian menunjukan bahwa: kerja tim berpengaruh secara langsung terhadap kinerja guru. Sedangkan berdasarkan hasil observasi penilaian kinerja guru pada umumnya menunjukan hasil bahwa guru di SMP Negeri dalam lingkup Kabupaten Wajo berada pada kategori amat baik. Kesimpulan penelitian ini adalah variabel bebas mempunyai pengaruh terhadap kinerja guru Sekolah Menengah Pertama Kabupaten Wajo. Artinya variabel dalam penelitian ini mempunyai peran penting dalam meningkatkan mutu kinerja guru.
\end{abstract}

Kata Kunci : tim kerja, kinerja guru

\section{PENDAHULUAN}

Tujuan pendidikan dalam undang-undang Republik Indonesia Nomor 20 tentang sistem pendidikan nasional (2003, pasal 5 ayat 1) menyebutkan bahwa setiap warga negara mempunyai hak yang sama untuk memperoleh pendidikan yang bermutu. Pendidikan yang bermutu diharapkan dapat menhasilkan sumber daya manusia yang berkualitas dalam menghadapi tantangan sesuai dengan tuntutan perubahan kehidupan lokal, nasional dan global. Kualitas pendidikan tentu akan berdampak pada kemampuan sumber daya manusia dalam menghadapi persaingan di era globalisasi. Rendahnya kualitas pendidikan jelas akan berimplikasi pada rendahnya kualitas pembangunan manusia yang dapat terlihat pula dari nilai Indeks Pembangunan Manusia (HDI). Posisi Indonesia berada pada rengking 108 yang jauh berada di bawah Malaysia yaitu rangking 61 demikian laporan UNDP tahun 2006. 
Perwujudan pendidikan yang berkualitas dapat dicapai jika dalam penyelenggaraan pendidikan, seluruh komponen yang terlibat memberikan kontribusi dan sinergis dalam melaksanakan peran dan fungsinya masingmasing baik dari unsur pimpinan, guru, tenaga administrasi maupun komponen lainnya. Untuk itu, pemerintah senantiasa berusaha meningkatkan kualitas sumber daya manusia pendidikan melalui peningkatan kompetensi guru, perbaikan kurikulum, perbaikan dalam evaluasi dan berusaha melibatkan stakcholder dalam pendidikan serta pembaharuan pendidikan secara terencana, terarah dan berkesinambungan.

Masalah mutu pendidikan di sekolah menengah pertama tidak lepas dari masalah tenaga pendidik sebagai agen pembelajaran. Sebagaimana yang diatur pada undang- undang Republik Indonesia nomor 14 tentang Guru dan Dosen (2005) pada pasal 4, kedudukan guru sebagai tenaga professional berfungsi untuk meningkatkan martabat bangsa dan peran guru sebagai agen pembelajaran dalam meningkatkan mutu pendidikan nasional. Dalam tataran mikro teknis, guru sebagai tenaga pendidik merupakan pemimpin pendidikan, dia amat menentukan dalam proses pembelajaran di kelas, ini berarti bahwa kinerja guru merupakan faktor yang amat menentukan bagi mutu pembelajaran yang akan berimplikasi pada kualitas output pendidikan. Kualitas kinerja guru akan sangat menentukan pada kualitas hasil pendidikan, karena guru merupakan pihak yang paling banyak bersentuhan langsung dengan siswa di Sekolah.

Pelaksanaan tugas guru tidak dapat dipisahkan dari kemampuan seorang guru dalam penguasaan pengetahuan, penerapan pengetahuan dan keterampilan sebagai kompetensi yang dibutuhkan dalam menjalankan tugas, namun yang menjadi permasalahan terdapatnya kesenjangan antara penyelenggaraan pendidikan yang belum sepenuhnya mampu menjawab tuntutan kebijakan "link and match", mutu, efisiensi dan efektifitas pendidikan dalam menghasilkan tenaga profesional sesuai dengan kebutuhan dan tuntutan perkembangan ilmu pengetahuan dan teknologi dalam era globalisasi.

Disisi lain, guru sebagian besar merasa mengajar hanya pemenuhan kewajiban tanpa merasa memiliki tanggung jawab moral terhadap tugas yang diberikan dalam pembinaan peserta didik. tugas guru secara umum yaitu tugas personal, tugas sosial dan tugas profesional, tugas profesional diperlukan penilaian kinerja yang menjamin terjadinya pengembangan keprofesian yang berkelanjutan, sehingga dapat memberikan bimbingan kepada siswa dalam rangka memenuhi kebutuhan dan minat siswa dalam proses pendidikan di sekolah.

Zane K. Quible (2005) mengemukakan faktor-faktor yang mempengaruhi kinerja menyatakan: "basic human traits affect employees' job related behaviour and performance. These human traits include ability, aptitude, perception, values, interest, emotions, needs and personality". Ability atau kemampuan akan menentukan bagaimana seseorang dapat melakukan pekerjaan, bakat akan berperan dalam membantu melaksanakan pekerjaan jika ada kesesuaian dengan jenis pekerjaannya, demikian juga halnya dengan persepsi, konsep diri, nilai-nilai, minat, emosi, kebutuhan dan kepribadian. Semua itu akan berpengaruh terhadap dorongan atau motivasi seseorang dalam melaksanakan pekerjaannya. Penerapan paradigma pendidikan, dimana tugas dan tanggung jawab guru menjadi semakin kompleks, sehingga dibutuhkan kompetensi dan kemampuan untuk menjalankan tugas yang diembannya yaitu sebagai pendidik, pengajar, pelatih, pembimbing, mengarahkan, menilai dan mengevaluasi serta perencana program pengajaran yang professional, guru juga dimungkinkan memiliki tugas-tugas lain yang relevan dengan fungsi sekolah. Oleh karena itu dalam penilaian kinerja guru beberapa sub unsur yang dinilai yaitu terkait pelaksanaan proses pembelajaran, meliputi kegiatan perencanaan dan pelaksanaan pembelajaran, menilai dan menganalisis hasil penilaian serta melaksanakan tindak lanjut hasil penilaian dalam menerapkan empat domain kompetensi yang harus dimiliki oleh guru sesuai dengan peraturan menteri pendidikan nasional No. 16 tahun 2007 tentang standar kualifikasi akademik dan kompetensi guru

Tugas guru membutuhkan kerja sama dan saling memberikan kontribusi oleh semua pihak baik teman sejawat, pimpinan, orang tua maupun siswa itu sendiri sehingga kerja tim harus tercipta dalam suasana kerja tim yang cerdas. Untuk mencapai keberhasilan dalam kerjasama tim, 
maka setiap anggota tim harus dapat melakukan pekerjaan dan memiliki kemampuan untuk inisiatif berdiskusi, mencari informasi dan opini, mengusulkan prosedur-prosedur untuk mencapai tujuan, mengelaborasi pendapat, dan menyimpulkan untuk menjadi suatu upaya yang dilakukan sebagai pertanggung jawaban dari tugas yang diamanatkan.

Guru sebagai kreator dalam proses pembelajaran mempunyai tugas utama untuk mengembangkan potensis siswa secara maksimal lewat penyajian materi pelajaran. Kebutuhan akan motivasi berprestasi merupakan dorongan untuk mengungguli, berprestasi sehubungan dengan seperangkat standar, bergulat untuk sukses. Ciri-ciri inidividu yang menunjukkan orientasi tinggi antara lain bersedia menerima resiko yang relatif tinggi, keinginan untuk mendapatkan umpan balik tentang hasil kerja mereka, keinginan mendapatkan tanggung jawab pemecahan masalah, disamping dari pada itu adanya rasa aman dan nyaman sehingga terjadi rasa kepuasan dalam menjalankan tugas dengan baik pada lingkungan kerja yang ditempati sehingga batin mereka merasakan kepuasan untuk menjalankan tugas tersebut.

Secara faktual bahwa nilai kompetensi guru SMP Kabupaten Wajo berdasarkan hasil uji kompetensi tahun 2012 yang dilaksanakan oleh tim UKG departemen pendidikan dan kebudayaan, dari 396 guru diperoleh nilai kompetensi yaitu rata-rata 46,79 yang berarti belum mencapai target 70 sebagai nilai standar, bahkan tim UKG memberikan rekomendasi untuk mengikuti diklat dasar sebanyak 258 dari 396 orang, ini pertanda bahwa $65 \%$ guru masih dibawah standar kompetensi dan hal ini merupakan salah satu bagian dari penilaian kinerja guru.

Menyikapi fenomena tersebut di atas maka kinerja guru menjadi sangat penting sebagai salah satu pemegang kunci dalam peningkatan sumber daya manusia, menarik untuk dilakukan melalui penelitian ilmiah terutama bagaimana pengaruh kerja tim dalam meningkatkan kinerja guru pada SMP Negeri Kabupaten Wajo.

Rumusan Masalah

Berdasarkan latar belakang masalah, maka pertanyaan dalam penelitian ini adalah: "Bagaimana pengaruh kerja tim terhadap kinerja guru" sehingga tujuan penelitian ini adalah untuk mengetahui pengaruh kerja tim terhadap kinerja guru, sedangkan hipotesis kerjanya adalah ada pengaruh kerja tim terhadap kinerja guru SMP negeri Kabupaten Wajo

\section{METODE PENELITIAN}

Jenis penelitian adalah metode deskriptif yaitu metode penelitian yang digunakan untuk menggambarkan dan menafsirkan keadaan yang terjadi pada masa kini. Metode deskriptif adalah sebuah metode penelitian yang berusaha menggambarkan dan menginterprestasikan objek sesuai dengan apa adanya (Sukardi,2003)

Penelitian ini menggunakan pendekatan kuantitatif yaitu proses menemukan pengetahuan yang menggunakan data berupa angka sebagai alat menemukan keterangan mengenai apa yang ingin diketahui. Jenis penelitian yang digunakan dalam penelitian ini adalah correlation study (mempelajari hubungan) yang dikelompokkan ke dalam kelompok penelitian asosiatif/hubungan dalam bentuk penyelesaian secara korelasi sederhana dan regresi ganda. Instrumen penelitian yang digunakan untuk pengumpulan data adalah angket.

Penelitian ini termasuk dalam penelitian eksploratif untuk membuktikan keterkaitan atau pengaruh antar variabel kerja tim terhadap kinerja guru, sedangkan pengembangan model yaitu model jalur yang dikembangkan.

pelaksanaan penelitian dilakukan pada Sekolah Menengah Pertama di Kabupaten Wajo Sulawesi Selatan. Populasi penelitian ini adalah semua guru negeri di SMP se-kabupaten Wajo yang jumlahnya 52 SMP negeri terdiri dari 4 tipe sekolah yaitu: 4 sekolah tipe A, 8 sekolah tipe B, 32 sekolah tipe $C$ dan 8 sekolah Tipe D. jumlah populasi adalah 744 orang (data 2013).

Pengkategorian tipe Sekolah ini diambil dari jumlah kelas secara keseluruhan pada setiap sekolah dengan ketentuan bahwa 4 atau lebih kecil jumlah rombongan belajar di sekolah itu dikategorikan tipe $\mathrm{D}, 5$ smpai 11 rombongan belajar dikatagorikan tipe C, 12 sampai 21 rombel dikategori tipe $\mathrm{B}$, dan 22 atau lebih besar dari jumlah rombel dikategorikan tipe $\mathrm{A}$

Jumlah populasi di atas begitu banyak, berdasarkan pertimbangan keterjangkauan waktu, dana dan tenaga yang dimiliki peneliti, 
maka jumlah sekolah yang menjadi sampel penelitian adalah 22 sekolah ( $50 \%$ ) dari jumlah sekolah tipe A, tipe B dan Tipe C, sedangkan tipe D tidak dijadikan sampel, karena jumlah guru di setiap sekolah tersebut sangat kecil dan tetap tewakili oleh sekolah dalam wilayah kecamatannya. Jadi sekolah yang menjadi populasi adalah 44 sekolah dengan jumlah guru sebanyak 744 guru. Teknik yang digunakan adalah propotional Claster Random Sampling, yaitu cara penarikan sampel yang dilakukan dengan dua tahap yaitu: Tahap I memilih secara acak sekolah dengan cara proposional berdasarkan tipe sekolah dan keterwakilan dari daerah kota, luar kota dan pinggir kabupaten. Tahap II yaitu semua guru yang ada dalam sekolah terpilih menjadi anggota sampel

Tabel 1: Daftar populasi dan sampel

\begin{tabular}{ccccc}
\hline No & Tipe Sekolah & $\begin{array}{c}\text { Populah } \\
\text { Sekolah }\end{array}$ & $\begin{array}{c}\text { Sampel } \\
\text { Sekolah }\end{array}$ & $\begin{array}{c}\text { Sampel Guru } \\
\text { yang diambil }\end{array}$ \\
\hline 1. & $\mathrm{~A}$ & 4 & 2 & 66 \\
2. & $\mathrm{~B}$ & 8 & 4 & 108 \\
3. & $\mathrm{C}$ & 32 & 16 & 120 \\
\hline & Jumlah & 44 & 22 & 294 \\
\hline
\end{tabular}

Defenisi operasional variabel penelitian ini sebagai berikut : Kerja tim (X); Yang dimaksud dengan kerja tim dalam penelitian ini adalah tugas, wewenang dan tanggung jawab yang dilaksanakan secara bersama dan saling terkait dalam mendukung keberhasilan tugas tersebut, dengan indikatornya : (1) mempunyai rasa memiliki; (2) bertanggung jawab; (3) Saling mempercayai dan (4) kerja kolektif.

Kinerja guru (Y); yang dimaksud dengan kinerja guru adalah sebagai berikut :(1) Perencanaan pembelajaran, (2) Pelaksanaan pembelajaran, (3). Evaluasi pembelajaran (4). Tindak lanjut hasil evaluasi.

Teknik dan alat pengumpulan data. Pengumpulan data dilakukan dengan menggunakan kuisioner berskala penilaian (ranting scale) dengan lima kategori pilihan jawaban. Dengan pernyataan positif : kategori selalu dengan nilai 5 ; kategori sering dengan nilai 4 ; kategori kadang-kadang dengan nilai 3 ; kategori jarang dengan nilai 2 ; dan kategori tidak pernah dengan nilai 1. Sebaliknya pernyataan negatif yaitu kategori selalu dengan nilai 1 , kategori sering dengan nilai 2 , kategori kadang-kadang dengan nilai 3, jarang dengan nilai 2 dan kategori tidak pernah dengan nilai 1 . Intrumen pengujian tersebut diuji keabsahan (validity) dan diuji keandalannya (reliability). Hasil uji coba validitas empiris instrumen penelitian ini dapat dilihat pada tabel 2 berikut ini

Tabel 2. Hasil analisis instrumen

\begin{tabular}{|c|c|c|c|c|c|c|c|}
\hline NO & VARIABEL & INDIKATOR & $\begin{array}{l}\text { CONSTRUC } \\
\text { VALIDITY }\end{array}$ & $\begin{array}{l}\text { ESTIM } \\
\text { ATE }\end{array}$ & S.E & C.R & $\mathrm{P}$ \\
\hline \multirow[t]{4}{*}{1} & Kinerja Guru & -Perencanaan pembelajaran & 0,93 & 1,00 & & & $<0,001$ \\
\hline & & -Pelaksanaan pembelajaran & 1,00 & 2,12 & 0,14 & 15,68 & $<0,001$ \\
\hline & & -Evaluasi pembelajaran & 0,96 & 1,42 & 0,11 & 13,19 & $<0,001$ \\
\hline & & -Tindak lanjut & 0,91 & 0,86 & 0,08 & 10,77 & $<0,001$ \\
\hline \multirow[t]{4}{*}{2} & Kerja tim & -Mempunyai rasa memiliki. & 0,98 & 1,00 & & & $<0,001$ \\
\hline & & -Bertanggung jawab. & 0,95 & 0,94 & 0,06 & 16,17 & $<0,001$ \\
\hline & & -Saling mempercayai. & 0,89 & 0,64 & 0,06 & 11,62 & $<0,001$ \\
\hline & & -Kerja kolektif. & 0,98 & 1,05 & 0,05 & 20,65 & $<0,001$ \\
\hline
\end{tabular}


Dari hasil analisis Construct Validity Empiric tergambar bahwa setiap indikator memberikan kontribusi terhadap peubah, hal ini memperlihatkan kesahihan konstruksi indikator yang kuat. Dari tabel di atas diperoleh penjelasan keberartian garis kontribusi melalui tabel nampak bahwa semua indikator secara empirik signifikan dalam membangun keberadaan kesahihan konstruksi indikator terhadap peubah laten. Karena itu indikator yang berada pada saat uji coba dapat digunakan sebagai alat ukur.

Selanjutnya instrumen menggunakan koefisien alpha cronbach. Koefisien keandalan alpha cronbach hanya dilakukan pada instrumen seperti hasil perhitungan reliabilitas itu dapat dilihat pada tabel 3 berikut;

Tabal 3. Hasil perhitungan reability

\begin{tabular}{clcc}
\hline No & \multicolumn{1}{c}{ Variabel } & Reability & Jumlah item \\
\hline 1 & Kinerja guru & 0,98 & 30 \\
2 & Kerja tim & 0,97 & 30 \\
\hline
\end{tabular}

Dari hasil analisis SPSS dimana Alpha Crombach Reliability diperoleh nilai reability yang menunjukan bahwa item tersebut secara keseluruhan memberikan kontribusi terhadap peubah laten. Teknik analisis data yang digunakan adalah teknik analisis data secara deskriptif dan inferensial. Perhitungan dilakukan dengan alat bantu komputer. Program yang digunakan adalah paket data analisis yang terdapat pada Microsoft Excel dan SPSS. Pengujian Analisis adalah menggunakan Analisis jalur (Path Analysis) mempersyaratkan data yang akan dianalisis memenuhi beberapa uji statistik.

\section{HASIL DAN PEMBAHASAN}

\section{Hasil}

Dalam kajian penelitian ini dikemukakan
analisis deskriptif penelitian, analisis konfirmatori masing-masing variabel, evaluasi kriteria goodness of fit model, pengujian hipotesis dan temuan penelitian.

Analisis deskriptif yang dikemukakan meliputi karakteristik responden, karakteristik responden seperti umur, jenis kelamin, pendidikan, dan pengalaman merupakan hal penting untuk diungkapkan sebab kemungkinan besar hal ini berdampak pada kinerja guru. Berdasarkan hasil penelitian diperoleh gambaran karakteristik responden seperti tertera pada tabel 4 berikut ini:
Tabel 4. Karakteristik Responden Menurut Jenis Kelamin

\begin{tabular}{ccc}
\hline No & $\begin{array}{c}\text { Jenis } \\
\text { Kelamin }\end{array}$ & Jumlah Guru \\
\hline 1. & Pria & 104 orang \\
2. & & 190 orang \\
& Perempuan & 294 orang \\
\hline
\end{tabular}

Jika dilihat dari jenis kelamin tercermin bahwa guru wanita lebih banyak dibandingkan guru pria yaitu guru wanita yang ada dikabupaten Wajo pada tingkat Sekolah Menengah Pertama adalah $65 \%$ sedangkan guru pria $35 \%$. Hal ini dapat memberikan kondisi pendidikan di Kabupaten Wajo.

Selanjutnya berdasarkan hasil penelitian data tentang karakteristik responden tentang umur diperoleh data sebagai berikut

Tabel 5. Karakteristik Responden Menurut Umur

\begin{tabular}{lccc}
\hline No & Umur & Frekuensi & $\begin{array}{c}\text { Persentase } \\
(\%)\end{array}$ \\
\hline 1. & 20 s.d 30 & 18 & 6,12 \\
2. & tahun & 70 & 23,81 \\
3. & 31 s.d 40 & 155 & 52,72 \\
4. & tahun & 51 & 17,35 \\
& 41 s.d 50 & & \\
& tahun & & \\
& 50 tahun & & \\
& ke atas & & \\
\hline
\end{tabular}




\begin{tabular}{lll}
\hline Jumlah & 294 & 100 \\
\hline
\end{tabular}

Hasil penelitian deskriptif tentang karakteristik variabel penelitian dimaksudkan memberikan gambaran tentang jawaban responden terhadap variabel-variabel kerja tim dan kinerja guru. Analisis dilakukan terhadap nilai-nilai parameter yang meliputi: nilai minimum, nilai maksimum, rata-rata, median, simpangan baku, tingkat persentase setiap indikator, dan nilai total setiap variabel.

Analisis parameter dilakukan terhadap parameter dengan mengadopsi kategorisasi yang dikemukakan oleh Arikunto (1998) dengan modifikasi seperlunya sebagai berikut, $86 \%$ -
$100 \%$ dikategorikan sangat tinggi atau sangat baik, 71\%-85\% dikategorikan tinggi atau baik, 56\%-70\% dikategorikan cukup tinggi atau cukup baik, 40\%-55\% dikategorikan kurang tinggi atau kurang baik, dan kurang dari $40 \%$ dikategorikan sangat rendah atau sangat tidak baik.

Analisis deksriptif Kerja Tim. Kerja tim mencakup 4 indikator yaitu mempunyai rasa memiliki $\left(X_{.1}\right)$, bertanggung jawab $\left(X_{.2}\right)$, saling mempercayai $\left(\mathrm{X}_{3}\right)$, kerja kolektif $\left(\mathrm{X}_{4}\right)$. Dari hasil analisis statistik dijelaskan sebagai berikut

Tabel 6. Statistik diskriptif kerja tim

\begin{tabular}{lcccccc}
\hline & N & Range & Min & Max & Mean & Std. Deviation \\
\hline \multirow{2}{*}{ Kerja Tim } & 294 & 14,75 & 22,50 & 37,25 & 30,73 & 2,74
\end{tabular}

Berdasarkan jumlah butir pernyataan pada variabel kerja tim yang telah dinyatakan valid dan reliabel sebanyak 30 butir instrumen, dengan rentangan skor 1-5. Skor minimal diperoleh 22,50 dan skor maksimal diperoleh 37,25 serta rata-rata (mean) diperoleh 30,73.
Standar deviasi sebesar 2,74. Karena selisih ratarata dan median dapat dikatakan tidak lebih dari satu standar deviasi, maka distribusi data komunikasi interpersonal cendrung berkontribusi normal.

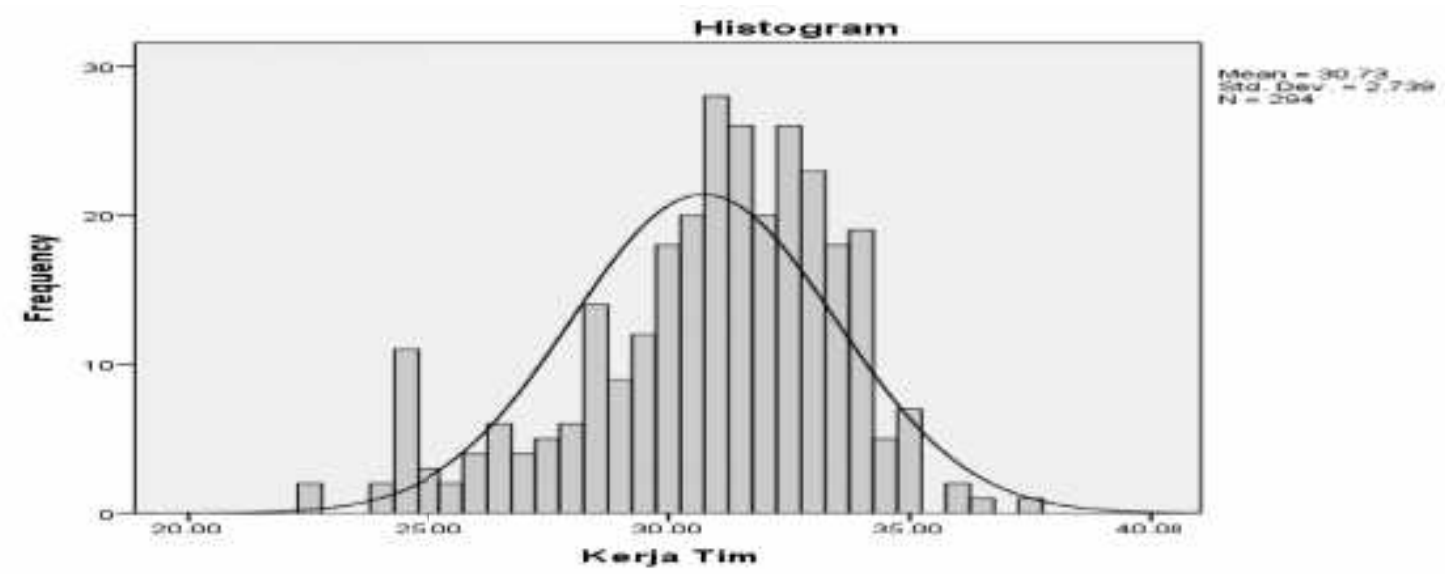

Gambar 1. Distribusi data variabel kerja tim

Secara grafik distribusi nilai kerja tim pada gambar 1. Distribusi tersebut adalah normal, hal ini dapat dibuktikan dari bentuk histogram normal, artinya karakteristik komunikasi interpersonal yang paling banyak dijumpai adalah kategori baik, dengan demikian bahwa komunikasi interpersonal termasuk baik. 
Tabel 7. Statistik analisis kesahihan konstruksi (Construct validity) kerja tim

\begin{tabular}{lllllll}
\hline Indikator & Variabel & Estimate & $\begin{array}{l}\text { Standar } \\
\text { Eror(S.E) }\end{array}$ & $\begin{array}{l}\text { Critical } \\
\text { Ratio } \\
\text { (R.C) }\end{array}$ & $\begin{array}{l}\text { Probabilit } \\
\text { y (P) }\end{array}$ & Keterangan \\
\hline $\mathrm{X}_{\cdot 1}$ & kerja tim & 0,71 & 0,05 & 12,40 & $<0,001$ & Signifikan \\
$\mathrm{X}_{2}$ & kerja tim & 0,62 & 0,06 & 10,47 & $<0,001$ & Signifikan \\
$\mathrm{X}_{\cdot 3}$ & kerja tim & 0,57 & 0,06 & 9,51 & $<0,001$ & Signifikan \\
$\mathrm{X}_{\cdot}$ & kerja tim & 0,84 & Fix & Fix & $<0,001$ & Signifikan \\
\hline
\end{tabular}

Secara konstruk, variabel Kerja Tim yang mengukur mempunyai rasa memiliki, bertanggung jawab, saling mempercayai dan kerja kolektif nampak bahwa keempat indikator signifikan mendukung atau memberi kontribusi pada keutuhan instrumen kerja tim. Urutan kontribusi untuk tiap indikator adalah kerja kolektif memberikan kontribusi terbesar kepada kerja tim yaitu 0,84 disusul oleh mempunyai rasa memiliki yaitu 0,71 , sedangkan indikator bertanggung jawab sebesar 0,62 serta saling mempercayai yang terkecil yaitu hanya 0,57 .

Analisis konstruk kinerja guru. Kinerja guru mencakup 4 Indikator yaitu (1) persiapan pembelajaran $\left(\mathrm{Y}_{\cdot_{1}}\right)$, pelaksanaan pembelajaran $\left(\mathrm{Y}_{.2}\right)$, evaluasi pembelajaran $\left(\mathrm{Y}_{.3}\right)$, tindak lanjut $\left(\mathrm{Y}_{4}\right)$. Dari hasil analisis statistik dijelaskan sebagai

berikut

Tabel 8. Statistik deskriptif kinerja guru

\begin{tabular}{lcccccc}
\hline & N & Range & Min & Max & Mean & $\begin{array}{c}\text { Std. } \\
\text { Deviation }\end{array}$ \\
\hline Kinerja guru & 294 & 12,50 & 24,00 & 36,50 & 31,07 & 2,07 \\
\hline
\end{tabular}

Berdasarkan jumlah butir pernyataan pada variabel komunikasi interpersonal yang telah dinyatakan valid dan reliabel sebanyak 30 butir instrumen, dengan rentangan skor 1-5. Skor minimal diperoleh 24,00 dan skor maksimal diperoleh 36,50 serta rata-rata (mean) diperoleh
31,07. Standar deviasi sebesar 2,07. Karena selisih rata-rata dan median dapat dikatakan tidak lebih dari satu standar deviasi, maka distribusi data komunikasi interpersonal cendrung berkontribusi normal.

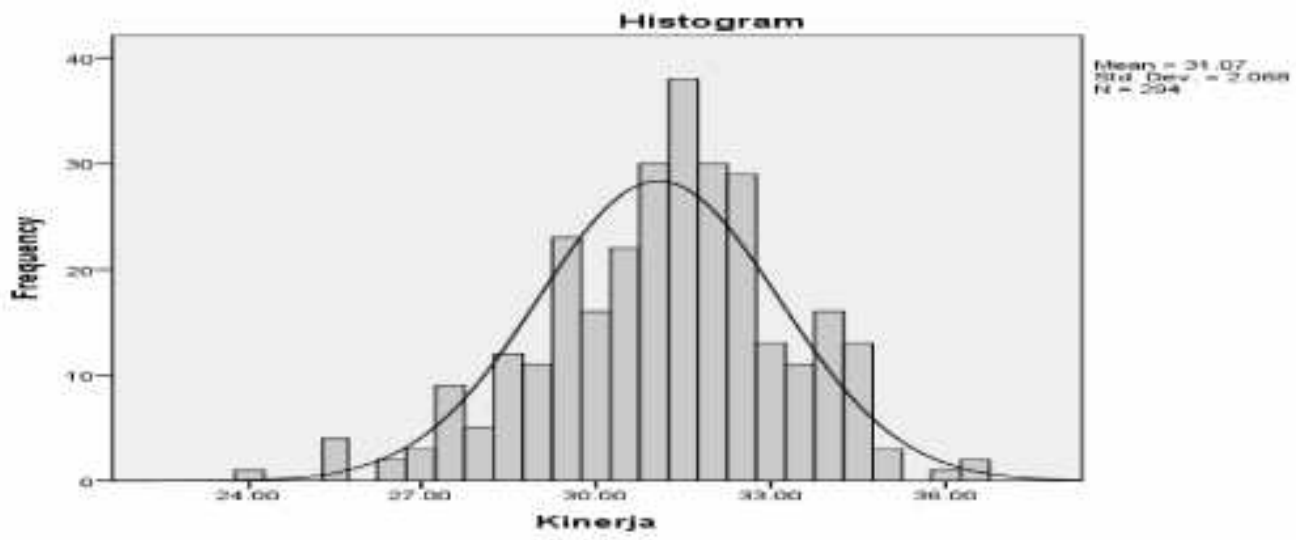

Gambar 2. Distribusi data variabel kinerja guru 
Secara grafik distribusi nilai kinerja guru pada gambar 2. Distribusi tersebut adalah normal, hal ini dapat dibuktikan dari bentuk histogram normal, artinya karakteristi komunikasi interpersonal yang paling banyak dijumpai adalah katagori baik, dengan demikian bahwa komunikasi interpersonal termasuk baik.

Tabel 9. Statistik analisis kesahihan konstruksi (Construct validity) kinerja guru

\begin{tabular}{lllllll}
\hline Indikator & Variabel & Estimate & $\begin{array}{l}\text { Standar } \\
\text { Eror(S.E) }\end{array}$ & $\begin{array}{l}\text { Critical } \\
\text { Ratio } \\
(\text { R.C })\end{array}$ & $\begin{array}{l}\text { Probabilit } \\
\text { y(P) }\end{array}$ & Keterangan \\
\hline $\mathrm{Y}_{\cdot 1}$ & kinerja guru & 0,67 & 0,26 & 6,41 & $<0,001$ & Signifikan \\
$\mathrm{Y}_{\cdot 2}$ & kinerja guru & 0,50 & 0,25 & 5,64 & $<0,001$ & Signifikan \\
$\mathrm{Y}_{\cdot 3}$ & kinerja guru & 0,83 & 0,39 & 6,77 & $<0,001$ & Signifikan \\
$\mathrm{Y}_{\cdot 4}$ & kinerja guru & 0,42 & Fix & Fix & $<0,001$ & Signifikan
\end{tabular}

Secara konstruk, variabel kinerja guru yang mengukur perencanaan pembelajaran, pelaksanaan pembelajaran, evaluasi pembelajaran dan tindak lanjut nampak bahwa keempat indikator signifikan mendukung atau memberi kontribusi pada keutuhan instrumen kinerja guru. Urutan kontribusi untuk tiap indikator adalah Pelaksanaan pembelajaran yang memberikan kontribusi yang paling tinggi yaitu 0,83 , disusul oleh indikator tindak lanjut yaitu 0,67 , kemudian disusul oleh indikator evaluasi pembelajaran yaitu 0,50 dan terakhir yaitu indikator persiapan pembelajaran dengan kontribusi 0,42 .

\section{Pembahasan}

Keberhasilan suatu pekerjaan dibutuhkan bantuan orang lain karena setiap pekerjaan selalu berhubungan dengan orang lain, oleh karena itu tim kerja yang cerdas dapat memaksimalkan pencapaian tujuan, artinya kecerdasan individu tidak menghasilkan yang terbaik tetapi kecerdasan kelompok yang menentukan hasil kerja.

Berdasarkan hasil output AMOS 20 diperoleh nilai CR(Critical Ratio) sebesar 1,47, nilai probabilitas eror 1,14 dan nilai estimasi sebesar 0,06 , artinya hipotesis yang menyatakan pengaruh kerja tim secara siqnifikan dan memberikan kontribusi terhadap kinerja guru. Walaupun dari beberapa hasil penelitian menunjukan bahwa kerja tim memberikan pengaruh secara langsung terhadap kinerja guru seperti yang dihasilkan peneliti Ilyas (2013) yaitu ada hubungan kerja tim dengan kinerja guru dengan koefisien korelasi 0,73 namun dari hasil penelitian ini menunjukan bahwa kerja tim memberikan kontribusi dan signifikan bila mana tercipta lingkungan kerja yang memberikan kepuasan kerja kepada guru untuk mengekspresikan kemampuan dan bekerja secara kompratif, sehingga dengan demikian dibutuhkan manajemen penataan lingkungan yang kondusif. Oleh karena itu pelaksanaan kegiatan guru baik secara internal sekolah maupun dalam bentuk musyawarah guru mata pelajaran (MGMP) atau kelompok kerja guru (KKG) perlu mendapat perhatian agar memberikan kontribusi terhadap kinerja guru. Dengan demikian dibuat suatu lingkungan yang membuat kepuasan peserta untuk mengikuti dan sistem sesuai dengan kebutuhan para guru sehingga guru merasa ada manfaat yang diperoleh pada kegiatan tersebut, bukan sekedar berkumpul hanya datang lebih banyak komunikasi diluar tujuan dari kegiatan tersebut. Oleh karena itu dibutuhkan program sehingga mereka termotivasi untuk mengikuti dan menerapkan segala konsep dan bahan pembelajaran yang dihasilkan.

Robbert W B (2012) berpendapat bahwa tim kerja merupakan upaya menumbuhkan kesadaran dan dukungan untuk bekerja sama secara bersinergi dalam satu tim yang saling mengenal, memahami, bertanggung jawab dalam membangun kepercayaan. Menyikapi pendapat tersebut jelas bahwa kerja tim sangat menentukan keberhasilan suatu lembaga pendidikan untuk mencapai tujuan, kerja sama setiap guru mata pelajaran baik mengkordinasikan materi pelajaran maupn 
membicarakan tentang kondisi pembinaan peserta didik yang sangat dibutuhkan, sehingga disepakati yang dapat dilakukan dan apa yang perlu menjadi program selanjutnya.

Sekolah yang efektif tidak bisa lepas dari budaya kerja yang diciptakannya. Jika suatu lingkungan organisasi sekolah tidak tercipta budaya kerja yang baik, maka kondisi seperti ini jelas sulit diharapkan untuk mewujudkan sekolah berprestasi, banyak masalah yang diidentifikasi yang harus dihadapi oleh organisasi sekolah secara bersama-sama dalam tim kerja. Berkaitan dengan terwujudnya sekolah berprestasi, hal itu tidak terlepas dari efektivitas kerja guru yang berada di organisasi sekolah tersebut. Efektivitas kerja guru pada dasarnya terfokus pada perilaku guru di dalam pekerjaannya. Sedangkan perihal efektivitas kerja guru dapat dilihat sejauh mana kinerja tersebut dapat memberikan pengaruh kepada anak didik. Secara spesifik tujuan kinerja juga mengharuskan para guru membuat keputusan khusus dimana tujuan pembelajaran dinyatakan dengan jelas dalam bentuk tingkah laku yang kemudian ditransfer kepada peserta didik. Penilaian terhadap kinerja merupakan faktor penting untuk meningkatkan kinerja dan kepuasan kerja guru, bagian-bagian yang menunjukkan kemampuan guru yang kurang, dapat diisi dan dilengkapi oleh guru yang lain. Inilah pentingnya kerja tim dalam membangun suatu sistem kerja yang efektif dan efesien.

Menyadari bahwa dirinya tidak hanya sebagai anggota dari organisasi sekolah yang membutuhkan kerja sama dan sinergitas untuk mengelolah setiap program, tetapi juga paham terhadap tujuan organsiasi sekolah tersebut, ini dibuktikan pada indikator kerja kolektif memberikan kontribusi 0,84 yang berarti cukup siqnifikan yang disumbangkan pada variabel kerja tim dan memberikan gambaran bahwa keberhasilan menyelesaikan suatu tugas ditentukan kerja sama yang baik antar guru mata pelajaran, guru dengan peserta didik serta unsur stekholder lainnya. Dengan demikian seorang guru akan dapat memahami sasaran dan kebijakan organisasi yang pada akhirnya dapat berbuat dan bekerja sepenuhnya untuk keberhasilan organisasi sekolah. Indikator kerja tim tentang mempunyai rasa memiliki dengan memberikan kontribusi 0,71 yang berarti cukup siqnifikan yang disumbangkan pada variabel kerja tim dan memberikan gambaran bahwa keberhasilan meningkatkan kinerja guru. Guru yang bersangkutan merasa bahwa tugas yang diberikan oleh sekolah adalah miliknya sendiri yang harus dijaga baik yang terkait dengan keberhasilan peserta didik, maupun sarana dan prasarana yang ada sehingga diolah dan dikembangkan dengan sebaik-baik deskriptif kerja tim. Dari hasil konsistensi setiap indikator dari kerja tim memberikan kontribusi yang cukup baik, Pengaruh kerja tim, memberikan kontribusi yang positif dan siqnifikan terhadap kinerja guru, yang artinya bahwa seorang guru dengan kerja tim yang baik dapat meningkatkan kinerjan secara maksimal, sebaliknya guru yang tidak dapat terjalin kerja sama dengan baik, kurang mendukung peningkatan kinerja dalam melaksanakan tugas.

Kontribusi indikator Kinerja guru.
Keempat indikator kinerja guru yaitu
perencanaan pembelajaran, pelaksnaan pembelajaran, evaluasi pembelajaran dan tindak lanjut hasil evaluasi pembelajaran, memberikan kontribusi secara signifikan dan dukungan yang besar terhadap kinerja guru, namun diantara indikator tersebut yang paling besar memberikan kontribusi adalah indikator pelaksanaan pembelajaran yaitu sebesar 0,83 ini menunjukan bahwa apapun yang direncanakan tanpa direalisasi tidak akan menghasilkan kinerja yang baik. Sebagai seorang pendidik kita semua memahami bahwa pembelajaran merupakan suatu yang kompleks, dimana tidak hanya transfer of knowledge atau menyampaikan pesan kepada peserta didik akan tetapi merupakan aktifitas profesional untuk menciptakan pembelajaran yang kondusif, inspiratif menantang dan menyenangkan.Tentu saja mencapai kondisi tersebut bukanlah hal yang mudah, karena menuntut keterampilan guru dalam menata dan melaksanakan pembelajaran didalam kelas ataupun diluar kelas.Oleh karena itu guru harus selalu mengembangkan wawasan dan pengetahuannya untuk memberikan yang terbaik dalam melaksanakan pembelajaran. Indikator kedua adalah tindak lanjut dari hasil evaluasi yaitu sebesar 0,67. Hal ini sebagai hasil refleksi terhadap proses dan hasil belajar siswa sangat kita perlukan untuk mengetahui letak kesalahan/kelemahan dan mengetahui penyebab kesalahan/kelemahan tersebut. Aktivitas berikutnya adalah mencari upaya-upaya yang seharusnya kita lakukan untuk mengoptimalkan 
pembelajaran kita. Berdasarkan hasil refleksi terhadap proses dan hasil evaluasi, kita melakukan tindak lanjut. Tindak lanjut hasil evaluasi kita arahkan untuk memantapkan aspek pembelajaran yang sudah baik dan memperbaiki aspek-aspek pembelajaran yang kurang/lemah. Oleh karena itu, refleksi terhadap proses dan hasil asesmen haruslah sampai pada ditemukannya faktor-faktor penyebab kegagalan dan pendukung keberhasilan pembelajaran. Berdasarkan identifikasi faktor-faktor penyebab kegagalan dan pendukung keberhasilan pembelajaran, akan dapat kita ketahui apakah kesalahan/kelemahan pembelajaran berada pada tahap perencanaan, pelaksanaan, atau penilaian. Karena pembelajaran merupakan suatu sistem, kesalahan salah satu tahap sangat mungkin terkait dengan kesalahan pada tahap yang lain. Dengan demikian, tindak lanjut hasil refleksi proses dan hasil evaluasi haruslah memperhatikan setiap komponen sistem dan keterkaitan antar komponen sistem itu. Dengan kata lain, kelemahan pada sebagian aspek pelaksanaan pembelajaran sangat mungkin terkait dengan kesalahan pada aspek perencanaan, karena pelaksanaan pembelajaran harus berpedoman pada rencana pembelajaran. Aktivitas tindak lanjut dapat kita mulai dari merancang perbaikan rencana pembelajaran, mengidentifikasi upaya-upaya mengoptimalkan proses pembelajaran, dan kemudian merancang pembelajaran remedial. Indikator evaluasi pembelajaran merupakan indikator ketiga terbesar memberikan kontribusi terhadap kinerja guru yaitu 0,50 yang berarti bahwa indikator ini turut memberi penguatan terhadap peubah kinerja guru. Evaluasi pembelajaran adalah suatu proses atau kegiatan yang sistematis, berkelanjutan dan menyeluruh dalam rangka pengendalian, penjaminan dan penetapan kualitas (nilai dan arti) berbagai komponen pembelajaran berdasarkan pertimbangan dan kriteria tertentu sebagai bentuk pertanggung jawaban guru dalam melaksanakan pembelajaran. Evaluasi pembelajaran merupakan sebuah kegiatan mengevaluasi atau mengoreksi hal-hal yang telah terjadi atau selama kegiatan pembelajaran yang telah berlangsung. Jadi jelas bahwa tidak ada perbaikan tanpa ada pelaksanaan evalusi yang dapat memberikan gambaran apa yang seharusnya diperbaiki dan ditindak lanjuti sebagai upaya peningkatan kinerja. Indikator yang terkecil memberikan kontribusi adalah persiapan pembelajaran yaitu sebesar 0,42. Tetapi bukan berarti peran dalam memberikan penguatan kinerja kecil, namun tetap memberikan kontribusi. Karena pelaksanaan pembelajaran adalah operasi-onalisasi dari perencanaan pembelajaran, sehingga tidak lepas dari perencanaan pembelajaran yang sudah dibuat. Oleh karenanya dalam pelaksanaannya akan sangat tergantung pada bagaimana perencanaan pengajaran sebagai operasionalisasi dari sebuah kurikulum. Pembelajaran akan menjadi sesuatu yang bermakna buat peserta didik ketika diupayakan melalui sebuah perencanan pembelajaran yang baik dan benar. Oleh karena itu, keterampilan guru dalam merancang pembelajaran merupakan sesuatu yang tidak bisa dipisahkan dengan tugas dan tanggung jawabnya sebagai seorang pendidik, pembelajar, dan seorang perancang pembelajaran. Pembelajaran, secara sederhana dapat diartikan sebagai upaya untuk membelajarkan siswa dan aktivitas belajar siswa tersebut dapat terjadi dengan direncanakan (by designed).Perencanaan merupakan aktivitas pendidikan dimana pembelajaran ada di dalamnya yang secara sadar dirancang untuk membantu siswa dalam mengembangkan potensi dirinya melalui sejumlah kompetensi yang diacunya dalam setiap proses pembelajaran yang diikutinya. Dalam aktivitas pembelajaran, sebagaimana aktivitas yang lain, perencanaan merupakan bagian yang penting yang akan menjadi pedoman dan panduan bagi pelaksanaan aktivitas itu. Tidak akan dicapai hasil yang memuaskan tanpa melalui perencanaan yang baik. Memang perencanaan yang baik dan matang saja belumlah cukup. Masih diperlukan lagi kesungguhan dalam mengorganisasikan rencana itu, melaksanakan kegiatan sesuai rencana, dan mengadakan penilaian hasil kegiatan. Aspek perencanaan merupakan bagian penting yang tak terpisahkan dari pengelolaan (manajerial) setiap kegiatan. Dalam pembelajaran, kita tentu memahami fungsi dan peran dari rencana pembelajaran, komponen pembelajaran serta prinsip-prinsip dalam menyusun rencana pembelajaran. Kita juga hendaknya paham bagaimana cara menyusun rencana pembelajaran, menilai baik/tidaknya rencana pembelajaran. Apa yang dapat kita lakukan terhadap rencana pembelajaran bila hasil 
pembelajaran tidak sesuai dengan harapan. Bagaimana cara memperbaiki rencana pembelajaran itu?. Sesungguhnya kegiatan menyusun rencana pembelajaran merupakan kegiatan tak terpisahkan dari tugas guru sebagai pelaksana dan pengelola pembelajaran. Sebelum melaksanakan pembelajaran, maka seharusnya kita dahului dan kita biasakan dengan kegiatan menyusun rencana pembelajaran. Sebagai penyusun, seyogyanya, kita juga harus mampu menilai kualitas dari rencana yang kita susun. Rencana pembelajaran yang berkualitas baik akan menjadi pedoman yang baik pula dalam tataran pelaksanaannya. Di samping mengetahui kualitas dari rencana pembelajaran yang kita buat, seyogyanya kita juga mampu menganalisa pada bagian mana dari rencana pembelajaran yang masih perlu dilakukan perbaikan. Tentu saja, dengan perbaikan yang kita lakukan, kualitas proses pembelajaran juga akan menjadi lebih baik dibanding sebelumnya.

Proses pembelajaran berlangsung dalam suasana tertentu yakni : terdapat faktor-faktor yang saling berhubungan yaitu; tujuan pembelajaran, siswa yang belajar, guru yang mengajar, bahan yang diajarkan, metode pembelajaran, alat bantu mengajar, prosedur penilaian, dan situasi pengajaran.Dalam proses pengajaran tersebut, semua faktor bergerak secara dinamis dalam suatu rangkaian yang terarah dalam rangka membawa para siswa/peserta didik untuk mencapai tujuan pembelajaran. Pengajaran merupakan suatu pola yang didalamnya tersusun suatu prosedur yang direncanakan dan terarah serta bertujuan. Dalam istilah lain, kegiatan pembelajaran terdiri dari : tahap perencanaan, pelaksanaan / implementasi, dan evaluasi serta mengiterprestasikan hasil evaluasi untuk dijadikan tindak lanjut perbaikan. Jika dihubungkan dengan hasil observasi kinerja guru sesuai instrumen Peraturan Menteri Negara Pendayagunaan Aparatur Negara dan Reformasi Birokrasi Nomor 16 Tahun 2009 tentang jabatan fungsional guru. Hasil penilaian kinerja guru melalui observasi yang dilaksanakan oleh Kepala Sekolah dan Wakil Kepala Sekolah masingmasing sekolah pada guru yang diamati dapat diperoleh hasil bahwa guru dengan status amat baik sebanyak $74 \%$, baik $23 \%$ dan cukup $3 \%$. Hal ini menunjukan bahwa pada umumnya guru Sekolah Menengah Pertama Negeri dalam lingkup Kabupaten Wajo memiliki kemampuan amat baik. Ini menunjukan bahwa setiap variabel kerja tim memberikan kontribusi yang baik kepada kinerja guru pada sekolah menengah pertama negeri di Kabupaten Wajo. Walaupun disadari ada beberapa membutuhkan perbaikan dan pembenahan sehingga dapat secara maksimal mendukung dan berkontribusi besar terhadap kinerja guru.

\section{SIMPULAN DAN SARAN}

Berdasarkan hasil pengujian hipotesis dan pembahasan, maka dapat disimpulkan sebagai berikut: Kerja tim berpengaruh secara langsung dan signifikan terhadap kinerja guru hal ini menunjukan bahwa kerja tim bisa berfungsi secara maksimal bila mana didukung oleh kondisi lingkungan yang memadai, sehingga termotivasi guru mengikuti kegiatan dalam rangka meningkatkan kinerjanya dapat terjalin dengan baik. Guru dapat mengembangkan kompetensinya bila mana tercipta kerja sama yang baik dengan guru lain atau ada suatu wadah yang bisa menjadikan tempat berkomunikasi, bertukar pikiran dan tempat penambahan wawasan, namun hal ini dapat terlaksana bilamana difasilitasi atau dikelola dengan baik tempat dan kegiatan sehingga para guru merasa nyaman dan tercipta kepuasan kerja yang lebih baik. Faktor-faktor pendukung kerja tim memberikan kontribusi positif dalam meningkatkan kinerja guru antara lain : mempunyai rasa memiliki yang artinya guru bekerja dengan penuh rasa tanggung jawab sehingga kelemahan hasil pekerjaan, mereka merasakan sebagai kekurangan dirinya sendiri. Dengan menyadari kekurangan guru maka mereka akan bertanggung jawab, yang artinya guru bertanggung jawab terhadap pekerjaan, saling mempercayai baik terhadap teman kerja maupun terhadap peserta didik khususnya dalam proses pembelajaran, kerja kolektif yang berarti : setiap pekerjaan dapat berhasil secara maksimal bila mana kerja sama yang baik dan secara komparatif dapat terjalin dengan baik.

Dari kesimpulan yang ensensial seperti yang dijelaskan, maka berikut ini akan dikemukakan saran : Sekolah sebagai bagian strategis pendidikan nasional, yang didalamnya tugas dan peran guru sangat penting, dibutuhkan strategi untuk peningkatan kinerja guru. Untuk 
hal tersebut Sekolah perlu meningkatkan fungsi guru dengan membekali pengetahuan tentang kemampuan bekerja sebagai satu tim yang cerdas agar mampu meningkatkan kinerja sehingga dapat mudah mentransfer ilmu pengetahuan kepada peserta didiknya.

Pendidikan merupakan suatu sistem dibutuhkan setiap komponen berkerja secara kompratif sehingga tugas dan fungsi sekolah berjalan sesuai program yang direncanakan. Dengan demikian perlu direvitalisasi dan diberdayakan organisasi kelompok guru serumpun di setiap sekolah agar berkerja sama secara internal maupun eksternal seperti kelompok kegiatan guru (KKG) dan musyawarah guru mata pelajaran (MGMP).Untuk itu diperlukan komitmen pemberdayaan dan perubahan sistem serta progaram yang lebih tepat agar guru merasa ada kepuasan kerja dan manfaat MGMP tersebut untuk tempat mengembangkan kompetensi diri dalam peningkatkan kinerja.

\section{DAFTAR RUJUKAN}

Arikunto,S. 2010. Management Pendidikan Jurnal Internasional. UNY.Yokyakarta

Huron, Arifin. 2009. Peran Kompetensi dan Tugas Kepala Sekolah Yang Efektif.Jurnal Internasional Manajemen Pendidikan, Volum 22 No 2. Malang.

Moerdiyanto. 2007. Manajemen Sekolah Indonesia yang Efektif Melalui Penerapan Total Quality Management. IMEC

Riduwan. 2008. Analisis Jalur. Bandung: Alfabeta.

Rini.R 2009. Daya Dukun Kepemimpinan Kepala Sekolah terhadap Peningkatan Kompetisi Guru. Malang : Jurnal Management Pendidikan. Volum 23 No 1.

Roberta,W, B. 2012 The Anonymity Factor in Making Multicultural Teams Work: Virtual and Real Teams:http://www.sagepub.com/jou rnalsPermissions.nav.

Sukardi. 2003. Metodologi Penelitian Pendidikan. Jakarta: Bumi Aksara
Tiro, Sukarna, Aswi. 2010. Analisis Jalur, Makassar: Andira publisher.

Undang-undang RI No. 20 tahun 2003.Sistim Pendidikan Nasional. Jakarta: Sinar Grafika.

Undang-undang RI No. 14 tahun 2005. 2006. tentang guru dan dosen. Bandung: Fokus media, Bandung.

Zane K. Quible. 2005. Manajemen Administrasi Perkantoran Modern. Jakarta: Erlangga 